(1CH

\title{
RESEARCH
}

\section{No detectable effect of a type 2 diabetes-associated TCF7L2 genotype on the incretin effect}

\author{
David S Mathiesen ${ }^{1}$, Jonatan I Bagger ${ }^{1}$, Katrine B Hansen², Anders E Junker ${ }^{3}$, Astrid Plamboeck ${ }^{4}$, Signe Harring5, ${ }^{*}$, \\ Thomas Idorn ${ }^{6, \dagger}$, Mads Hornum ${ }^{2,4,6}$, Jens J Holst ${ }^{7}$, Anna E Jonsson ${ }^{7}$, Torben Hansen ${ }^{7}$, Tina VilsbølI 1,7,8, Asger Lund ${ }^{1,9}$ \\ and Filip K Knop 1,2,7,8,9
}

\author{
${ }^{1}$ Center for Clinical Metabolic Research, Gentofte Hospital, University of Copenhagen, Hellerup, Denmark \\ ${ }^{2}$ Department of Clinical Medicine, Faculty of Health and Medical Sciences, University of Copenhagen, Copenhagen, Denmark \\ ${ }^{3}$ Department of Gastroenterology, Hvidovre Hospital, University of Copenhagen, Hvidovre, Denmark \\ ${ }^{4}$ Center for Cancer and Organ Diseases, Rigshospitalet, University of Copenhagen, Copenhagen, Denmark \\ ${ }^{5}$ Novartis Healthcare A/S, Copenhagen, Denmark \\ ${ }^{6}$ Department of Nephrology, Rigshospitalet, University of Copenhagen, Copenhagen, Denmark \\ ${ }^{7}$ Novo Nordisk Foundation Center for Basic Metabolic Research, Faculty of Health and Medical Sciences, University of Copenhagen, \\ Copenhagen, Denmark \\ ${ }^{8}$ Steno Diabetes Center Copenhagen, Gentofte, Denmark \\ ${ }^{9}$ Department of Medicine, Gentofte and Herlev Hospital, University of Copenhagen, Denmark
}

Correspondence should be addressed to A Lund or F K Knop: asger.lund.01@regionh.dk or filip.krag.knop.01@regionh.dk

*(S Harring is now at Novartis Healthcare A/S, Copenhagen, Denmark)

${ }^{\dagger}(T$ Idorn is now at Novo Nordisk A/S, Søborg, Denmark)

\begin{abstract}
The T allele of TCF7L2 rs7903146 is a common genetic variant associated with type 2 diabetes (T2D), possibly by modulation of incretin action. In this study, we evaluated the effect of the TCF7L2 rs7903146 T allele on the incretin effect and other glucometabolic parameters in normal glucose tolerant individuals (NGT) and participants with T2D. The rs7903146 variant was genotyped in cohorts of 61 NGT individuals (23 were heterozygous (CT) or homozygous (TT) T allele carriers) and 43 participants with T2D (20 with CT/TT). Participants were previously examined by an oral glucose tolerance test (OGTT) and a subsequent isoglycemic intravenous glucose infusion (IIGI). The incretin effect was assessed by quantification of the difference in integrated beta cell secretory responses during the OGTT and IIGI. Glucose and hormonal levels were measured during experimental days, and from these, indices of beta cell function and insulin sensitivity were calculated. No genotype-specific differences in the incretin effect were observed in the NGT group $(P=0.70)$ or the T2D group $(P=0.68)$. NGT T allele carriers displayed diminished glucose-dependent insulinotropic polypeptide response during OGTT $(P=0.01)$ while T allele carriers with T2D were characterized by lower C-peptide AUC after OGTT $(P=0.04)$ and elevated glucose AUC after OGTT $(P=0.04)$. In conclusion, our findings do not exclude that this specific TCF7L2 variant increases the risk of developing T2D via diminished incretin effect, but genotype-related defects were not detectable in these cohorts.
\end{abstract}
Key Words
- TCF7L2
- transcription factor 7-like 2
- SNP
- incretin effect
- incretins
type 2 diabetes

https://ec.bioscientifica.com https://doi.org/10.1530/EC-20-0471

c 2020 The authors Published by Bioscientifica Ltd
Endocrine Connections (2020) 9, 1221-1232 


\section{Introduction}

Type 2 diabetes is a multifactorial disorder with environmental triggers such as a sedentary lifestyle, physical inactivity and ensuing overweight. Genetic predisposition also plays an important role in the development of the disease, as shown by studies in twins and families with type 2 diabetes $(1,2)$. Type 2 diabetes is characterized by hyperglycemia due to insulin resistance and a progressive loss of beta cell function. The pathogenesis of type 2 diabetes also involves chronic hyperglucagonemia and a severely reduced incretin effect $(3,4,5)$. The incretin effect refers to the greater insulin response during oral glucose ingestion compared to isoglycemic intravenous (IV) glucose infusion (IIGI) (5). The incretin effect is mediated by the two gut hormones glucose-dependent insulinotropic polypeptide (GIP) and glucagon-like peptide 1 (GLP-1) (6). These hormones are secreted from enteroendocrine $\mathrm{K}$ and $\mathrm{L}$ cells, situated in the intestinal mucosa, in response to ingestion of nutrients. Both GIP and GLP-1 are insulinotropic in a glucose-dependent manner, that is, when glucose levels are elevated above fasting levels (7).

In 2006, it was discovered that a common SNP in TCF7L2 was associated with type 2 diabetes in an Icelandic population (8). This finding has been replicated in European, North American and other ethnic groups (9, $10,11)$, and to date, the T allele of the SNP rs7903146 located within the TCF7L2 gene is a strong genetic predictor of type 2 diabetes with an odds ratio of $\sim 1.4$ per allele $(8,12,13)$. The molecular mechanisms linking the $T$ allele of the TCF7L2 variant rs7903146 and the increased risk of type 2 diabetes remain uncertain. TCF7L 2 encodes a widely expressed transcription factor in the Wnt/ $\beta$-catenin signaling pathway (14). TCF7L2 may also exert its effect via regulation of neighboring genomic regions (15). The TCF7L2 variant has been linked to impaired incretin-stimulated insulin secretion as well as changes in incretin metabolism in a number of studies $(12,16,17,18$, $19,20,21,22,23,24)$. Additionally, functional studies of rs7903146 suggest that TCF7L2 activity has effects related to gastric function, early onset of type 2 diabetes, hepatic lipid metabolism, pancreatic islet function, proinsulin conversion and insulin synthesis and secretion (10, 25, $26,27,28,29,30,31,32,33)$. Together, these findings point to a central role for TCF7L2 in the pathogenesis of some type 2 diabetes phenotypes. In $\mathrm{T}$ allele carriers with obesity and/or impaired glucose tolerance, the incretin effect is reduced compared to their $\mathrm{C}$ allele carrier counterparts $(17,24)$. However, the specific contribution of the $\mathrm{T}$ allele to the reduced incretin effect observed in these studies is difficult to disentangle as both obesity and reduced glucose intolerance is associated with a reduced incretin effect $(34,35)$. Nevertheless, the well-described impaired incretin effect in patients with type 2 diabetes may to some extent be caused by this specific genetic variation in TCF7L2 $(17,24)$. We, therefore, evaluated the impact of the T allele of TCF7L2 rs7903146 on the incretin effect in individuals with normal glucose tolerance and participants with type 2 diabetes separately to see if the findings from previous functional association studies applying the same methods as here were reproducible in these groups of participants.

\section{Materials and methods}

\section{Subjects}

One hundred and four participants (34 females) from 8 separate studies in which the incretin effect had been investigated using OGTTs and IIGIs were included in the present study $(4,34,36,37,38,39,40,41)$. Only individuals with normal glucose tolerance and participants with type 2 diabetes from these studies were included in our analysis, and thus, participants with end-stage renal disease, maturity-onset diabetes in the young or vagotomy were excluded. Sixty-one participants displayed normal glucose tolerance and 43 participants were diagnosed with type 2 diabetes according to WHO criteria at least 3 months before inclusion in the original studies. All participants with normal glucose tolerance were healthy, without family history of diabetes and had normal glucose tolerance according to an oral glucose tolerance test (OGTT) performed immediately before inclusion in the study. Participants with type 2 diabetes were diagnosed according to the criteria of the World Health Organization at least 3 months before inclusion in the original studies. After a washout period of no less than a week, none of the participants with type 2 diabetes were treated with drugs likely to affect the responses of glucose, insulin, C-peptide, GIP or GLP-1 during experimental days. All were well treated with regard to plasma lipids and blood pressure. None of the participants had impaired renal function, microalbuminuria or proliferative retinopathy. Eight had non-alcoholic fatty liver disease (NAFLD) in addition to type 2 diabetes; diagnosed based on histology and graded according to the quantity of hepatic fat infiltration (NAFLD $\geq 5 \%$ fat infiltration). 
All participants were between 21 and 80 years of age, negative with regard to islet cell autoantibodies and glutamic acid decarboxylase-65 autoantibodies. Additional medications, if any, were paused for $12 \mathrm{~h}$ in both groups. All subjects agreed to participate after receiving oral and written information. The protocol for the present study was approved by the Scientific-Ethical Committee of the Capital Region of Denmark (registration no. H-12014-104).

\section{Study protocol and experimental procedures}

All experiments were performed following the same protocol in our group and has been described thoroughly elsewhere $(4,34,36,37,38,39,40,41)$. In short, all participants were studied on two occasions: (i) during an OGTT (with a time frame of minimum $3 \mathrm{~h}$ ) and; (ii) during a subsequent IIGI where the individual plasma glucose levels from the preceding OGTT were mimicked. The OGTT and the IIGI days were separated by at least $24 \mathrm{~h}$. Before each occasion, the participants with type 2 diabetes were instructed not to take their oral antidiabetic therapy (if any) for a week. On both occasions, the participants were studied in the morning after an overnight fast (10 h) including liquids, medications and tobacco. On the day of the OGTT, the participants ingested 50 or $75 \mathrm{~g}$ of water-free glucose dissolved in water. Arterialized venous blood (i.e. drawn from a heated extremity) was drawn at regular intervals $(0,10,20,30,40,50,60,75,90,120$, 150 and $180 \mathrm{~min}$ ) after ingestion of glucose to determine plasma/serum concentrations of glucose, glucagon, GLP-1, GIP, insulin and C-peptide. Subsequently, the IIGIs were performed using 20\% (w/v) glucose infusion. The infusion rate was adjusted to copy the plasma glucose profile during the OGTT. Arterialized blood was sampled as on OGTT days, except for more frequent plasma glucose sampling to adjust the glucose infusion rate.

\section{Biochemical analyses}

Analyses for serum insulin and C-peptide and plasma glucose, glucagon, total GIP and total GLP-1 were performed as previously described $(4,34,36,37,38,39$, $40,41)$.

\section{Genotyping}

DNA was prepared from blood sample lymphocytes and the TCF7L2 rs7903146 polymorphism was genotyped by the Illumina Infinium HumanCoreExome Beadchip platform (Illumina, San Diego, CA). Genotypes were obtained using the Genotyping module (version 1.9.4) of GenomeStudio software (version 2011.1, Illumina). Standard quality control was applied (42).

\section{Calculations}

AUC values were calculated using the trapezoidal rule and are presented as total or incremental AUC. Incremental AUC was calculated as baseline-subtracted, and consequently includes both positive and negative areas related to baseline. Incretin effect was calculated by relating the difference in integrated beta cell secretory responses between stimulation with OGTT and IIGI to the response after OGTT, which was taken as 100\% (incretin effect $\left.(\%)=100 \% \times\left(\mathrm{AUC}_{\text {OGTT }}-\mathrm{AUC}_{\mathrm{IIGI}}\right) / \mathrm{AUC}_{\text {OGTT }}\right)(5)$. The insulinogenic index $\mathrm{x}_{30 \text { min }}\left(\mathrm{IGI}_{30}\right)$, an estimate of beta cell function from the OGTT, was calculated by relating the increment of insulin to that of plasma glucose 30 min after glucose ingestion $\left(\mathrm{IGI}_{30}=\left(\mathrm{I}_{30}-\mathrm{I}_{0}\right) /\left(\mathrm{G}_{30}-\mathrm{G}_{0}\right)\right.$ ) (43). Oral glucose-insulin sensitivity ${ }_{120 \mathrm{~min}}\left(\mathrm{OGIS}_{120}\right)(44)$, an assessment of insulin sensitivity from the OGTT, was calculated using the glucose values at time points 0,90 and $120 \mathrm{~min}$ and insulin values at time points 0 and 90 min of the OGTT (44). Disposition index was calculated by relating the beta cell function index to the insulin sensitivity index $\left(\mathrm{IGI}_{30} / \mathrm{OGIS}_{120}\right)$. There were small differences in blood sampling intervals between studies, therefore, missing data from four studies at time points 40, 50 and 75 min were generated by linear extrapolation of existing data points.

\section{Statistical analyses}

Data are presented as means \pm s.e.M. unless otherwise stated. Group differences in gender distribution and OGTT glucose dose were compared using the $\mathrm{Chi}^{2}$ test for independence. Group differences in anthropometrics and parameters of glucose homeostasis were compared using the appropriate two-tailed unpaired Student's $t$-test. Group differences in AUCs were tested by ANOVA using a mixed model including subject ID as random factor and glucose dose during OGTT as co-variance structure with the 'nlme' package in the statistical software $R$. Multivariate linear regression analyses were performed in both groups to adjust for the potential effects of age, BMI, glucose dose during OGTT and gender on the incretin effect, 2-h plasma glucose after OGTT, insulin sensitivity $\left(\right.$ OGIS $\left._{120}\right)$, beta cell function $\left(\mathrm{IGI}_{30}\right)$ and disposition index. One outlier was excluded from the analysis due to a highly implausible

This work is licensed under a Creative Commons Attribution-NonCommercial-NoDerivatives 4.0 elfternationad ficense.ifica.com at 04/26/2023 09:37:46AM 
incretin effect $(-460 \%)$. The absence of multicollinearity was confirmed by the variance inflation factor with a cutoff value of 1.5 using the 'car' package in $R$. To avoid false negatives in our relatively small dataset, no correction for multiple comparisons was applied. Thus, $P$ values $<0.05$ were considered statistically significant. For all statistical analysis, $R$ statistical software version 3.6.1 was used (www.r-project.org).

\section{Power analysis}

Standard deviations from a previously published study (17) was used to calculate the power of our analysis. In the normal glucose tolerance group, we estimated that with 23 participants in each group, we would have $84.1 \%$ power to detect differences in the incretin effect of $10 \%$ between the two groups with a significance level of 0.05 in an unpaired two-sided $t$-test. With slightly fewer participants in the type 2 diabetes group, the corresponding power level was $78.6 \%$ to detect differences of $10 \%$ between the two groups with a significance level of 0.05 in an unpaired two-sided $t$-test.

\section{Results}

\section{Characteristics of the study participants}

We studied 61 individuals with normal glucose tolerance of whom 22 were heterozygous carriers of the TCF7L2 rs7903146 T allele (CT) and one was homozygous T allele carrier (TT). Forty-three subjects with type 2 diabetes were studied, of whom 15 were heterozygous carriers of the $\mathrm{T}$ allele (CT) and five were homozygous $\mathrm{T}$ allele carriers (TT). Participants with type 2 diabetes and NAFLD were distributed evenly in the two genotype groups. The homozygous individuals did not appear to be different from the heterozygous subjects with regards to their incretin effect and subject characteristics and were, therefore, analyzed with the heterozygous T allele carriers. No differences in age, $\mathrm{BMI}$, fasting plasma glucose, $\mathrm{HbA}_{1 \mathrm{c}}$, 2-h plasma glucose after OGTT, beta cell function, insulin sensitivity, peak plasma glucose or fasting hormone concentrations between $\mathrm{T}$ allele carriers and non-carriers were observed in the normal glucose tolerance group (Table 1). There were significant differences in peak plasma glucose $(17.0 \pm 0.6(\mathrm{CC})$ vs $18.9 \pm 0.6(\mathrm{CT} / \mathrm{TT})$ $\mathrm{mmol} / \mathrm{L}, P=0.02$ ) and plasma glucose 2 -h after OGTT $(13.5 \pm 0.6(\mathrm{CC})$ vs $15.2 \pm 0.5(\mathrm{CT} / \mathrm{TT}) \mathrm{mmol} / \mathrm{L}, P=0.04$ after adjusting for age, gender, BMI and glucose dose) in
Table 1 Anthropometric and metabolic data of the normal glucose tolerance group.

\begin{tabular}{|c|c|c|c|}
\hline & \multicolumn{3}{|c|}{ Normal glucose tolerance group } \\
\hline & CC & $\mathrm{CT} / \mathrm{TT}$ & $P$ \\
\hline $\mathrm{n}(\mathrm{f} / \mathrm{m})$ & $14 / 24$ & $3 / 20$ & 0.09 \\
\hline $\begin{array}{l}\text { 50/75 g-OGTT } \\
(n / n)\end{array}$ & $21 / 17$ & $14 / 9$ & 0.87 \\
\hline Age (years) & $51.1 \pm 2.5$ & $46.1 \pm 3.7$ & 0.28 \\
\hline $\mathrm{BMI}\left(\mathrm{kg} / \mathrm{m}^{2}\right)$ & $26.5 \pm 0.8$ & $24.9 \pm 0.9$ & 0.18 \\
\hline FPG (mmol/L) & $5.3 \pm 0.05$ & $5.2 \pm 0.08$ & 0.48 \\
\hline $\begin{array}{l}\mathrm{HbA}_{1 \mathrm{c}}(\mathrm{mmol} / \\
\mathrm{mol})(\%)\end{array}$ & $35.8 \pm 0.5(5.35)$ & $36.2 \pm 0.5(5.4)$ & 0.51 \\
\hline $\begin{array}{l}\text { 2-h glucose } \\
(\mathrm{mmol} / \mathrm{L})\end{array}$ & $5.4 \pm 0.2$ & $5.0 \pm 0.2$ & $0.17 / 0.11^{a}$ \\
\hline$|G|_{30}$ & $119 \pm 13$ & $110 \pm 13$ & $0.66 / 0.85^{a}$ \\
\hline $\begin{array}{l}\mathrm{OGIS}_{120}(\mathrm{~mL} \times \\
\left.\min \times \mathrm{m}^{2}\right)\end{array}$ & $406 \pm 6.9$ & $424 \pm 8.9$ & $0.10 / 0.39^{a}$ \\
\hline $\begin{array}{l}\text { Disposition } \\
\text { index }_{30}\end{array}$ & $0.31 \pm 0.04$ & $0.27 \pm 0.04$ & $0.43 / 0.90^{a}$ \\
\hline $\begin{array}{l}\text { Peak glucose } \\
(\mathrm{mmol} / \mathrm{L})\end{array}$ & $9.6 \pm 0.2$ & $9.8 \pm 0.3$ & $0.65 / 0.59^{a}$ \\
\hline $\begin{array}{l}\text { Fasting insulin } \\
(\mathrm{pmol} / \mathrm{L})\end{array}$ & $55.0 \pm 4.4$ & $57.4 \pm 6.9$ & 0.94 \\
\hline $\begin{array}{l}\text { Fasting } \\
\text { C-peptide } \\
\text { (pmol/L) }\end{array}$ & $635 \pm 51$ & $601 \pm 43$ & 0.80 \\
\hline $\begin{array}{l}\text { Fasting } \\
\text { glucagon } \\
\text { (pmol/L) }\end{array}$ & $6.7 \pm 0.6$ & $7.5 \pm 0.5$ & 0.17 \\
\hline $\begin{array}{l}\text { Fasting GLP-1 } \\
(\mathrm{pmol} / \mathrm{L})\end{array}$ & $11.9 \pm 1.0$ & $11.5 \pm 1.0$ & 0.93 \\
\hline $\begin{array}{l}\text { Fasting GIP } \\
(\mathrm{pmol} / \mathrm{L})\end{array}$ & $11.3 \pm 0.9$ & $14.7 \pm 1.5$ & 0.05 \\
\hline
\end{tabular}

Data are means \pm S.E.M.

${ }^{a}$ Adjusted for age, BMI, sex and glucose dose (75/50 g) in a multivariate linear model.

FPG, fasting plasma glucose; GIP, glucose-dependent insulinotropic polypeptide; GLP-1, glucagon-like peptide $1 ;\left.I\right|_{30}$, insulinogenic index (30 min); OGIS $_{120}$, oral glucose insulin sensitivity (from 120 min oral glucose tolerance test).

the type 2 diabetes group (Table 2). The remaining subject characteristics and glucometabolic parameters were similar among $\mathrm{T}$ allele carriers and non-carriers in the type 2 diabetes group (Table 2). Based on multivariate linear regression analyses using age, sex, OGTT glucose dose (50/75 g), BMI and TCF7L2 (CC or CT/TT) as independent variables, no significant interaction between the TCF7L2 rs7903146 $\mathrm{T}$ allele and $\mathrm{IGI}_{30}$, OGIS ${ }_{120}$ or disposition index $_{30}$ was detected in the normal glucose tolerance group (Table 1) or in the type 2 diabetes group (Table 2).

\section{Glucose and hormone levels during OGTT and IIGI}

In the normal glucose tolerance group (Fig. 1 and Table 3), the $\mathrm{T}$ allele of rs7903146 was associated with decreased secretion of GIP in response to OGTT. This was most

This work is licensed under a Creative Commons Attribution-NonCommercial-NoDerivatives 4.0 Internationab License ifica com at $04 / 26 / 2023$ 09:37:46AM 
Table 2 Anthropometric and metabolic data of the type 2 diabetes group.

\begin{tabular}{|c|c|c|c|}
\hline & \multicolumn{3}{|c|}{ Type 2 diabetes group } \\
\hline & CC & $\mathrm{CT} / \mathrm{TT}$ & $P$ \\
\hline $\mathrm{n}(\mathrm{f} / \mathrm{m})$ & $12 / 11$ & $14 / 6$ & 0.38 \\
\hline $\begin{array}{l}\text { 50/75 g OGTT } \\
(\mathrm{n} / \mathrm{n})\end{array}$ & $20 / 3$ & $17 / 3$ & 1.00 \\
\hline Age (years) & $61.3 \pm 2.2$ & $55.9 \pm 2.2$ & 0.09 \\
\hline $\begin{array}{l}\text { Duration of } \\
\text { diabetes } \\
\text { (months) }\end{array}$ & $56.2 \pm 10.6$ & $38.8 \pm 8.5$ & 0.21 \\
\hline BMI $\left(\mathrm{kg} / \mathrm{m}^{2}\right)$ & $32.2 \pm 1.3$ & $29.5 \pm 1.1$ & 0.12 \\
\hline FPG (mmol/L) & $8.6 \pm 0.3$ & $9.4 \pm 0.4$ & 0.12 \\
\hline $\begin{array}{c}\mathrm{HbA}_{1 \mathrm{c}}(\mathrm{mmol} / \\
\mathrm{mol})(\%)\end{array}$ & $49.0 \pm 1.5(6.6)$ & $51.7 \pm 1.7(6.9)$ & 0.25 \\
\hline $\begin{array}{l}\text { 2-h glucose } \\
\text { (mmol/L) }\end{array}$ & $13.5 \pm 0.6$ & $15.2 \pm 0.5$ & $0.05 / 0.04^{a}$ \\
\hline $\mathrm{IGI}_{30}$ & $32.8 \pm 6.4$ & $25.3 \pm 5.9$ & $0.39 / 0.82^{a}$ \\
\hline $\begin{array}{l}\mathrm{OGIS}_{120}(\mathrm{~mL} \times \\
\left.\min \times \mathrm{m}^{2}\right)\end{array}$ & $296 \pm 8.8$ & $278 \pm 8.1$ & $0.15 / 0.19^{a}$ \\
\hline $\begin{array}{l}\text { Disposition } \\
\text { index }_{30}\end{array}$ & $0.13 \pm 0.03$ & $0.08 \pm 0.02$ & $0.19 / 0.51^{a}$ \\
\hline $\begin{array}{l}\text { Peak glucose } \\
(\mathrm{mmol} / \mathrm{L})\end{array}$ & $17.0 \pm 0.6$ & $18.9 \pm 0.6$ & $0.02 / 0.02^{a}$ \\
\hline $\begin{array}{l}\text { Fasting insulin } \\
(\mathrm{pmol} / \mathrm{L})\end{array}$ & $121 \pm 16.6$ & $96.9 \pm 12.1$ & 0.43 \\
\hline $\begin{array}{l}\text { Fasting } \\
\text { C-peptide } \\
\text { (pmol/L) }\end{array}$ & $1,220 \pm 125$ & $918 \pm 84$ & 0.13 \\
\hline $\begin{array}{l}\text { Fasting } \\
\text { glucagon } \\
\text { (pmol/L) }\end{array}$ & $8.7 \pm 0.7$ & $9.6 \pm 1.2$ & 0.73 \\
\hline $\begin{array}{l}\text { Fasting GLP-1 } \\
(\mathrm{pmol} / \mathrm{L})\end{array}$ & $13.5 \pm 1.2$ & $15.6 \pm 1.1$ & 0.14 \\
\hline $\begin{array}{l}\text { Fasting GIP } \\
(\mathrm{pmol} / \mathrm{L})\end{array}$ & $19.8 \pm 5.0$ & $20.8 \pm 4.0$ & 0.89 \\
\hline
\end{tabular}

Data are means \pm S.E.M. Significant $P$ values $(<0.05)$ shown in bold. ${ }^{a}$ Adjusted for age, $\mathrm{BMI}$, sex and glucose dose $(75 / 50 \mathrm{~g})$ in a multivariate linear model.

FPG, fasting plasma glucose; GIP, glucose-dependent insulinotropic polypeptide; GLP-1, glucagon-like peptide $1 ; \mid \mathrm{IGI}_{30}$, insulinogenic index (30 min); OGIS 120 , oral glucose insulin sensitivity (from 120 min OGTT).

pronounced when analyzing incremental AUC for GIP $(5349 \pm 400(\mathrm{CC})$ vs $3631 \pm 513(\mathrm{CT} / \mathrm{TT}) \mathrm{min} \times \mathrm{pmol} / \mathrm{L}$, $P=0.01$ ) (Table 3), and less so in the AUC for GIP $(7643 \pm 414(\mathrm{CC})$ vs $6623 \pm 535(\mathrm{CT} / \mathrm{TT}) \mathrm{min} \times \mathrm{pmol} / \mathrm{L}$, $P=0.11$ ) (Table 3). Apart from this, the T allele was not associated with any differences in circulating levels of glucose, insulin, C-peptide, glucagon nor GLP-1 during OGTT or IIGI. Expectedly, there were significantly greater AUCs for insulin, C-peptide, glucagon, GLP-1 and GIP during OGTT compared to IIGI. This was independent of the genotype studied.

In the type 2 diabetes group (Fig. 2 and Table 4), incremental AUC for glucose was significantly lower after OGTT in the non-carriers compared to T-allele carriers
$(2198 \pm 79(\mathrm{CC})$ vs $2446 \pm 84 \mathrm{~min} \times \mathrm{mmol} / \mathrm{L}, P=0.04)$. Additionally, incremental AUCs for C-peptide during OGTT were significantly lower in the $\mathrm{T}$ allele carriers compared to non-carriers in the type 2 diabetes group (365 \pm 26 (CC) vs $277 \pm 28(\mathrm{CT} / \mathrm{TT}) \min \times \mathrm{nmol} / \mathrm{L}, P=0.04)$. Otherwise, insulin, glucagon, GLP-1 and GIP hormone responses did not differ between genotype groups. The route of glucose administration was a consistent and significant determinant for glucagon, GLP-1 and GIP responses, which were greater during OGTT compared to IIGI in both groups.

\section{Incretin effect}

As shown in Table 3, the normal glucose tolerance group displayed no statistically significant difference in any estimate of incretin effect between genotype groups. In a multivariate linear model adjusting for TCF7L2 rs7903146 genotype, OGTT glucose dose (50/75 g), age, gender and BMI, only BMI could significantly predict the magnitude of the incretin effect (with increasing BMI leading to a decreasing incretin effect). In the type 2 diabetes group (Table 2), no differences in incretin effect estimates were found in any analysis performed. Here, no covariables in the multivariate linear regression significantly predicted the magnitude of the incretin effect. Expectedly, all estimates of the incretin effect were significantly lower in the type 2 diabetes group as compared to the normal glucose tolerance group $(P<0.001)$. A sensitivity analysis revealed no significant changes in the results when the participants with NAFLD and type 2 diabetes were excluded from analysis.

\section{Discussion}

In the cohorts studied here, we could not detect reduced incretin effect in carriers of the risk $\mathrm{T}$ allele of TCF7L2 rs7903146 among participants with normal glucose tolerance or among participants with type 2 diabetes. In the normal glucose tolerant risk allele carriers, we observed a diminished GIP response to OGTT as compared to noncarriers. This was not observed in $\mathrm{T}$ allele carriers in our cohort of participants with type 2 diabetes, but these displayed lower C-peptide and elevated glucose levels after OGTT compared to non-carriers. There were no differences between normal glucose tolerant carriers and non-carriers with regard to insulin or C-peptide responses to oral or IV glucose. This is in agreement with other studies utilizing OGTTs in heterozygous and homozygous T allele carriers $(17,18,19,20)$. 
A
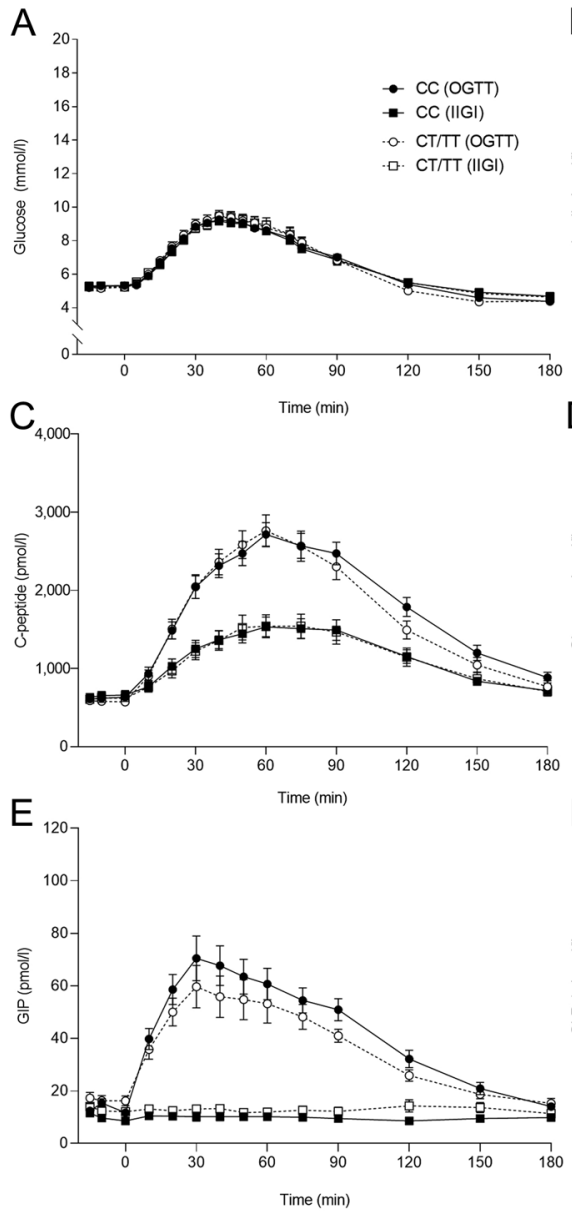

$\mathrm{B}$
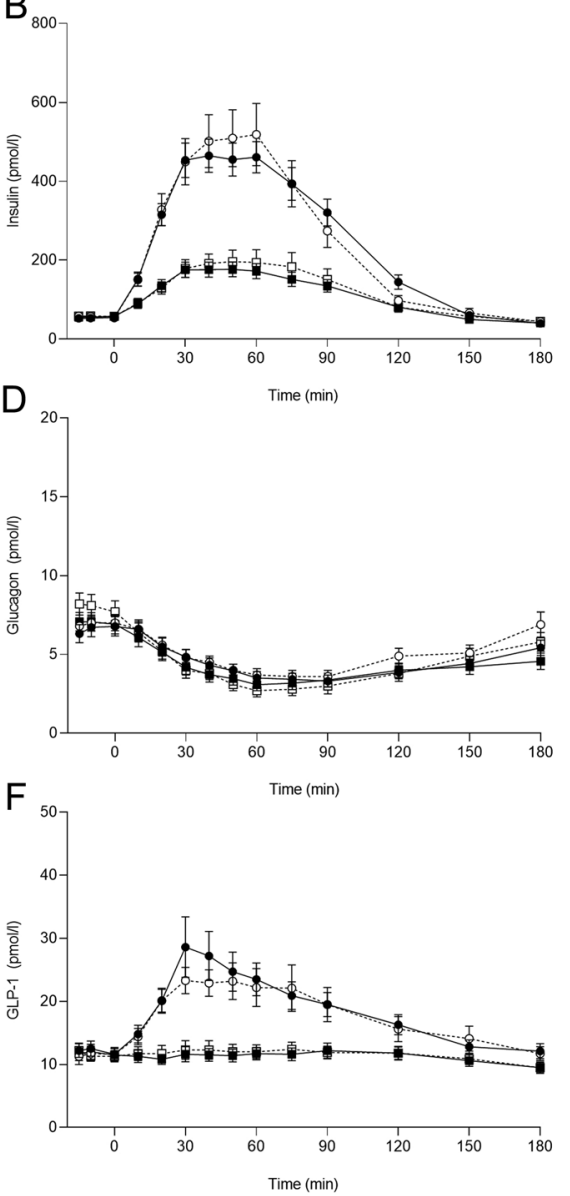

Figure 1

Concentrations of plasma glucose $(A)$, serum insulin (B), serum C-peptide (C), plasma glucagon (D), plasma glucose-dependent insulinotropic polypeptide (GIP) (E) and plasma glucagon-like peptide 1 (GLP-1) (F) of CC homozygotes (full line and filled symbols) and T allele carriers (dotted line and open symbols) with normal glucose tolerance during OGTT (circles) and isoglycemic IV glucose infusion (IIGI) (squares). Data are means \pm S.E.M.
The findings in our study are in contrast with findings from other functional association studies in which the T allele of TCF7L2 rs7903146 was found to impair the incretin effect $(17,24)$ or incretin-induced insulin secretion during a hyperglycemic clamp $(18,19)$. In a study by Villareal et al. including 18 individuals (8 with CT/TT) with normal or impaired glucose tolerance, carriers of the risk $\mathrm{T}$ allele were characterized by a diminished incretin effect (measured by OGTT/IIGI method) compared to homozygous C allele carriers (17). This finding has been reproduced by Galderisi et al., who found the OGTT/IIGI-derived incretin effect to be reduced in $\mathrm{T}$ allele carriers compared to $\mathrm{C}$ allele carriers in a group of 39 obese adolescents with normal or impaired glucose tolerance (24). Supporting this, Schäfer et al. conducted a sophisticated study in which 73 individuals (38 with CT/ TT) underwent a hyperglycemic clamp with a continuous IV GLP-1 infusion (1.5 pmol/kg min) (18). In this setting, a defect in the insulinotropic action of exogenous GLP-1 was observed in carriers of the TCF7L2 rs7903146 risk T allele with normal and impaired glucose tolerance (18). Using a similar design, the impact of the rs7903146 T allele on insulin secretion in response to exogenous GIP and GLP-1, respectively, was studied in normal glucose tolerant males with normal weight by Pilgaard et al. (19). Forty-four rs7903146 homozygous C allele carriers (CC) vs 37 risk allele carriers (CT/TT) were subjected to three hyperglycemic clamps $(7 \mathrm{mmol} / \mathrm{L})$ with infusion of GLP-1 (1 pmol/kg min), GIP (4 pmol/kg min) and saline, respectively, showing diminished insulinotropic action of GLP-1 and GIP in T allele carriers. In line with this, the $\mathrm{T}$ allele carriers displayed reduced 24-h insulin concentrations and reduced insulin secretion during a mixed meal test, but not during an IVGTT. Additionally, the $\mathrm{T}$ allele carriers were characterized by increased hepatic glucose production despite reduced 24-h glucagon levels. In another study, the incretin effect was quantified in 235 individuals with impaired fasting glucose $(>5.4 \mathrm{mmol} / \mathrm{L})$ by an OGTT followed by an IVGTT (with glucose bolus injection), and as such, not by the gold standard method (12). Here, carriers of the TCF7L2 rs7903146 risk T allele were characterized by a slightly (3.5\%) lower insulin response to oral relative to IV glucose as compared to noncarriers (12). Some factors may account for the difference

This work is licensed under a Creative Commons Attribution-NonCommercial-NoDerivatives 4.0 Internationab dicense.ifica.com at 04/26/2023 09:37:46AM 
Table 3 Differences in incretin effect and AUCs for glucose and hormones in the normal glucose tolerance group.

\begin{tabular}{|c|c|c|c|c|c|c|}
\hline & \multicolumn{6}{|c|}{ Normal glucose tolerance group } \\
\hline & \multicolumn{3}{|c|}{ Total AUC } & \multicolumn{3}{|c|}{ Incremental AUC } \\
\hline & CC $(n=38)$ & $\mathrm{CT} / \mathrm{TT}(n=23)$ & $P$ & CC $(n=38)$ & $\mathrm{CT} / \mathrm{TT}(n=23)$ & $P$ \\
\hline \multicolumn{7}{|c|}{ Glucose $(\min \times \mathrm{mmol} / \mathrm{L})$} \\
\hline OGTT & $1264 \pm 33$ & $1213 \pm 42$ & 0.34 & $312 \pm 29$ & $279 \pm 37$ & 0.40 \\
\hline IIGI & $1262 \pm 33$ & $1210 \pm 42$ & 0.34 & $307 \pm 29$ & $267 \pm 37$ & 0.51 \\
\hline$P$ & 0.98 & 0.87 & & 0.97 & 0.60 & \\
\hline \multicolumn{7}{|l|}{ Insulin (min $\times$ nmol/L) } \\
\hline OGTT & $44.4 \pm 3.0$ & $43.5 \pm 3.9$ & 0.79 & $34.8 \pm 2.3$ & $33.3 \pm 3.0$ & 0.66 \\
\hline IIGI & $19.8 \pm 3.0$ & $21.4 \pm 3.9$ & 0.81 & $9.6 \pm 2.3$ & $10.9 \pm 3.0$ & 0.71 \\
\hline$P$ & $<0.001$ & $<0.001$ & & $<0.001$ & $<0.001$ & \\
\hline Incretin effect (\%) & $54.8 \pm 2.5$ & $51.6 \pm 3.2$ & $0.44 / 0.39^{a}$ & $72.2 \pm 2.6$ & $71.9 \pm 3.7$ & $0.78 / 0.70^{a}$ \\
\hline \multicolumn{7}{|c|}{ C-peptide $(\min \times \mathrm{nmol} / \mathrm{L})$} \\
\hline OGTT & $327.0 \pm 16$ & $308.3 \pm 21$ & 0.61 & $215.1 \pm 10$ & $203.6 \pm 13$ & 0.58 \\
\hline IIGI & $207.7 \pm 16$ & $207.3 \pm 21$ & 1.00 & $90.8 \pm 10$ & $95.8 \pm 13$ & 0.89 \\
\hline$P$ & $<0.001$ & $<0.001$ & & $<0.001$ & $<0.001$ & \\
\hline Incretin effect (\%) & $36.6 \pm 2.5$ & $33.6 \pm 3.3$ & $0.46 / 0.64^{a}$ & $57.3 \pm 2.9$ & $55.2 \pm 3.6$ & $0.64 / 0.82^{a}$ \\
\hline \multicolumn{7}{|c|}{ Glucagon $(\min \times \mathrm{pmol} / \mathrm{L})$} \\
\hline OGTT & $762.3 \pm 61$ & $874.9 \pm 79$ & 0.19 & $-397.3 \pm 55$ & $-374.7 \pm 71$ & 0.71 \\
\hline IIGI & $634.5 \pm 61$ & $695.8 \pm 79$ & 0.24 & $-628.6 \pm 55$ & $-744.2 \pm 71$ & 0.20 \\
\hline$P$ & $<0.001$ & $<0.01$ & & $<0.001$ & $<0.001$ & \\
\hline \multicolumn{7}{|l|}{ GLP-1 $(\min \times \mathrm{pmol} / \mathrm{L})$} \\
\hline OGTT & $3297 \pm 155$ & $3213 \pm 192$ & 0.87 & $1136 \pm 107$ & $1142 \pm 132$ & 0.95 \\
\hline$\| G \mid$ & $1834 \pm 155$ & $1922 \pm 192$ & 0.30 & $-274.5 \pm 107$ & $-162 \pm 132$ & 0.54 \\
\hline$P$ & $<0.001$ & $<0.001$ & & $<0.001$ & $<0.001$ & \\
\hline \multicolumn{7}{|l|}{$\mathrm{GIP}(\min \times \mathrm{pmol} / \mathrm{L})$} \\
\hline OGTT & $7643 \pm 414$ & $6623 \pm 535$ & 0.11 & $5349 \pm 400$ & $3631 \pm 513$ & 0.01 \\
\hline IIGI & $1528 \pm 414$ & $2003 \pm 535$ & 0.49 & $-242 \pm 400$ & $-313 \pm 513$ & 0.90 \\
\hline$P$ & $<0.001$ & $<0.001$ & & $<0.001$ & $<0.001$ & \\
\hline
\end{tabular}

Data are means \pm S.E.M. Significant $P$ values $(<0.05)$ are shown in bold.

${ }^{a}$ Adjusted for age, BMI, sex and glucose dose $(75 / 50 \mathrm{~g})$ in a multivariate linear model.

GIP, glucose-dependent insulinotropic polypeptide; GLP-1, glucagon-like peptide 1; IIGl, isoglycemic IV glucose infusion.

between previous conclusions and our results: (i) In most of the abovementioned studies, individuals with impaired glucose tolerance were overrepresented in the $\mathrm{T}$ allele groups, and (ii) A BMI difference of $2.3 \mathrm{~kg} / \mathrm{m}^{2}$ between non-carrier and risk allele carrier groups in the study by Villareal et al. may explain some of the incretin effect variance between the two groups, as the analysis was not adjusted for BMI. It is well known that impaired glucose tolerance as well as overweight/obesity are associated with a reduced incretin effect $(34,35)$. Thus, it seems reasonable to adjust for these factors when delineating the effects of the TCF7L2 genotype on the incretin effect (45). Despite adjusting for relevant variables, our analysis could not detect reduced incretin effect in the $\mathrm{T}$ allele carriers observed here. The range of the observed differences in the normal glucose tolerance group were 69 and 90\% for incretin effects derived from incremental insulin and C-peptide AUCs, respectively. In the type 2 diabetes group, the range of the observed differences were 90 and $214 \%$ for incretin effects derived from incremental insulin and C-peptide AUCs, respectively. In T allele carriers with normal glucose tolerance, it is very likely that the incretin effect is only trivially reduced, as previously reported (12). As our study was powered to detect differences of $10 \%$, we cannot exclude a significant difference lower than $10 \%$. In a previous report by our group, a $12 \%$ reduction of the incretin effect did not affect glucose tolerance (34), and our results seem to confirm this, since normal glucose tolerant $\mathrm{T}$ allele carriers were not different than $\mathrm{C}$ allele carriers with regard to any of the metabolic parameters evaluated here. Taken together, $\mathrm{T}$ allele carriers with normal glucose tolerance do not seem to be characterized by incretin-related metabolic abnormalities despite their genetic predisposition to diminished incretin action. On the other hand, $\mathrm{T}$ allele carriers with metabolic dysfunction (i.e. obesity or impaired glucose tolerance) consequently display reduced incretin effect $(17,18$, 24 ), thus confirming the effect of this genetic locus on incretin action. Our study is the first to evaluate the TCF7L2-specific defects in the incretin effect in $\mathrm{T}$ allele carriers with type 2 diabetes. The previously reported effect of the TCF7L2 genotype on incretin action does not

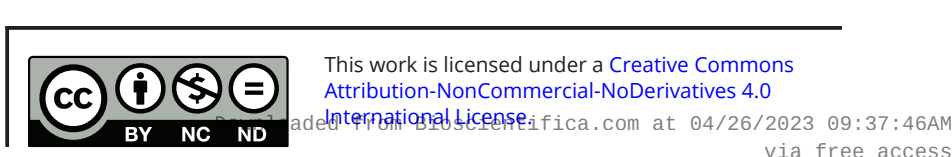



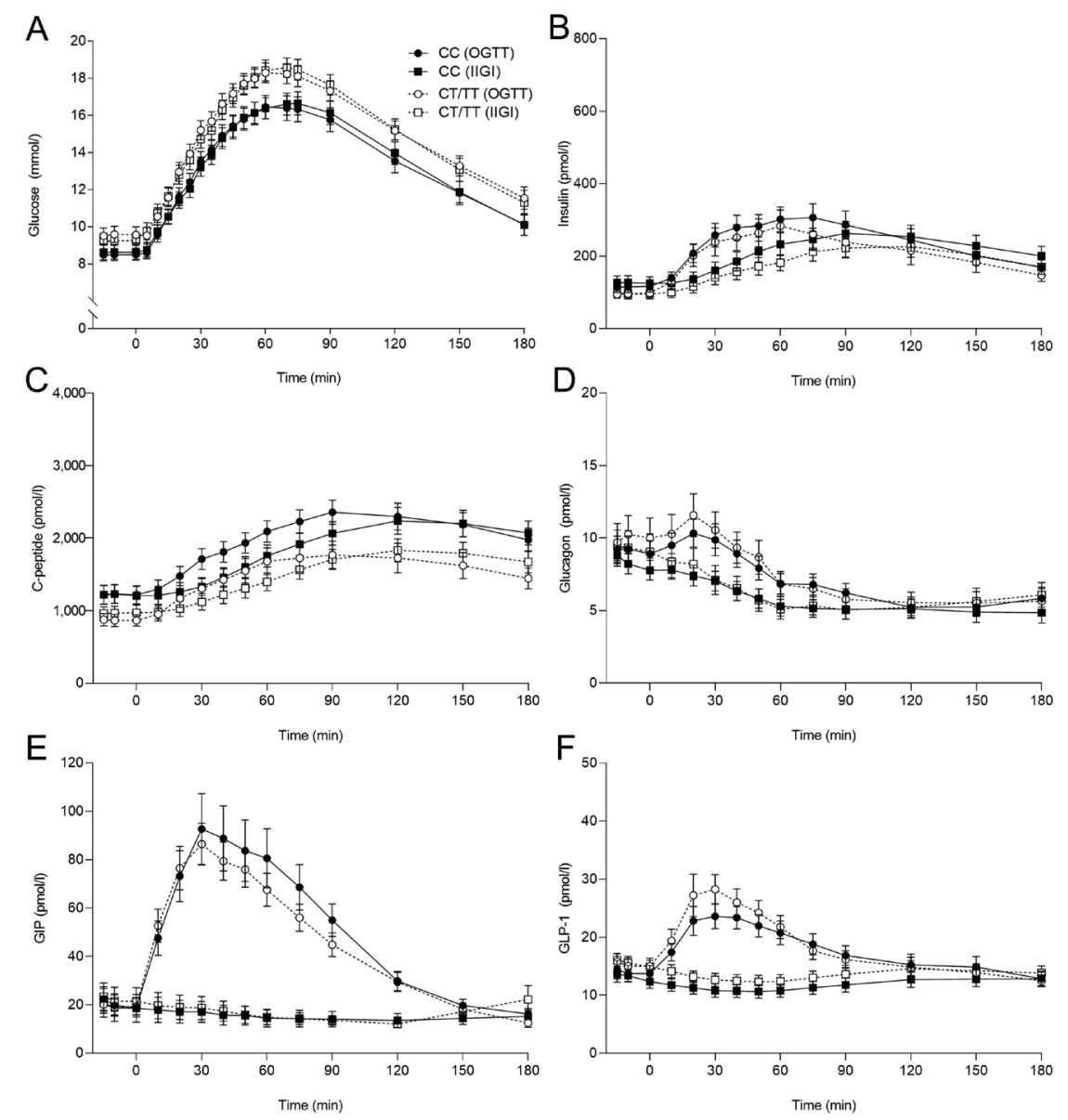

\begin{abstract}
Figure 2
Concentrations of plasma glucose (A), serum insulin (B), serum C-peptide (C), plasma glucagon (D), plasma glucose-dependent insulinotropic polypeptide (GIP) (E) and plasma glucagon-like peptide 1 (GLP-1) (F) of CC homozygotes (full line and filled symbols) and T allele carriers (dotted line and open symbols) with type 2 diabetes during OGTT (circles) and isoglycemic IV glucose infusion (IIGI) (squares). Data are means \pm s.E.M.
\end{abstract}

seem to translate into this group of participants, and the characteristic diminished incretin effect in the diabetic state is most likely independent from TCF7L2 genotype.

Reduced fasting concentrations of GIP and AUC for GIP during an OGTT have previously been observed in a mixed normal/impaired glucose tolerance group including both heterozygous and homozygous T allele carriers (20). Other functional association studies have reported either unaffected or elevated GIP levels in response to an OGTT or a meal test in $\mathrm{T}$ allele carriers with normal or impaired glucose tolerance $(16,17,19,31)$. In the present study, we observed diminished GIP incremental AUC in response to OGTT in risk allele carriers with normal glucose tolerance only. This finding may relate to the leaner phenotype of the $\mathrm{T}$ allele carriers as a higher BMI seems to be associated with increased GIP secretion (46).

Our results are in agreement with studies reporting no genotype-specific effects on GLP-1 levels in individuals with normal or impaired glucose tolerance during an OGTT or a meal test $(16,17,19,20,21,25,26,31)$. However, in a cohort of individuals with risk factors for type 2 diabetes or lifestyle-controlled type 2 diabetes, a subset of 50 homozygous T allele carriers (TT) displayed elevated baseline levels of GLP-1 (22). This is in contrast with the findings in our study but may relate to the higher number of participants in the other study and the larger proportion of homozygous T allele carriers (TT) amongst these. Other factors contributing to the contrasting results may include differences in BMI, age and the ratio between males and females (especially in the CT/TT group) between this and the abovementioned study. We observed a decreased C-peptide AUC during OGTT in carriers of the TCF7L2 rs7903146 T allele among individuals with type 2 diabetes. Resonating with this, AUC for glucose and peak plasma concentration of glucose during OGTT were significantly higher in these participants compared to their non-carrier counterparts. Taken together, these observations may suggest a beta cell secretory defect in TCF7L2 rs7903146 T allele carriers with type 2 diabetes. In line with this, association studies have consistently reported defective beta cell function in T allele carriers (9, $10,33,47)$. As no beta cell secretory deficits were detectable among $\mathrm{T}$ allele carriers in our normal glucose tolerance group, our results may indicate that the effect of the

This work is licensed under a Creative Commons Attribution-NonCommercial-NoDerivatives 4.0 elnternationab dicense ifica.com at 04/26/2023 09:37:46AM 
Table 4 Differences in incretin effect and AUCs for glucose and hormones in the type 2 diabetes group.

\begin{tabular}{|c|c|c|c|c|c|c|}
\hline & \multicolumn{6}{|c|}{ Type 2 diabetes group } \\
\hline & \multicolumn{3}{|c|}{ Total AUC } & \multicolumn{3}{|c|}{ Incremental AUC } \\
\hline & $\mathrm{CC}(n=23)$ & $\mathrm{CT} / \mathrm{TT}(n=20)$ & $P$ & $\mathrm{CC}(n=23)$ & $\mathrm{CT} / \mathrm{TT}(n=20)$ & $P$ \\
\hline \multicolumn{7}{|c|}{ Glucose $(\min \times \mathrm{mmol} / \mathrm{L})$} \\
\hline OGTT & $2198 \pm 79$ & $2446 \pm 84$ & 0.04 & $665 \pm 46$ & $725 \pm 49$ & 0.35 \\
\hline||$G \mid$ & $2226 \pm 79$ & $2444 \pm 84$ & 0.06 & $667 \pm 46$ & $770 \pm 49$ & 0.16 \\
\hline$P$ & 0.14 & 0.85 & & 0.76 & 0.15 & \\
\hline \multicolumn{7}{|l|}{ Insulin $(\min \times \mathrm{nmol} / \mathrm{L})$} \\
\hline OGTT & $43.0 \pm 4.7$ & $38.2 \pm 5.6$ & 0.44 & $22.2 \pm 2.8$ & $20.9 \pm 3.0$ & 0.38 \\
\hline$\| G \mid$ & $38.8 \pm 4.7$ & $33.3 \pm 5.1$ & 0.50 & $16.0 \pm 2.8$ & $15.8 \pm 3.0$ & 0.98 \\
\hline$P$ & $<0.01$ & 0.02 & & $<0.01$ & 0.20 & \\
\hline Incretin effect (\%) & $12.5 \pm 4.0$ & $11.5 \pm 5.2$ & $0.88 / 0.68^{a}$ & $28.3 \pm 6.9$ & $6.6 \pm 11.5$ & $0.12 / 0.29^{a}$ \\
\hline \multicolumn{7}{|c|}{ C-peptide $(\min \times \mathrm{nmol} / \mathrm{L})$} \\
\hline OGTT & $365 \pm 26$ & $277 \pm 28$ & 0.04 & $145 \pm 12$ & $121 \pm 13$ & 0.11 \\
\hline$\| G \mid$ & $336 \pm 26$ & $275 \pm 28$ & 0.14 & $116 \pm 12$ & $101 \pm 13$ & 0.41 \\
\hline$P$ & 0.18 & 0.95 & & 0.01 & 0.26 & \\
\hline Incretin effect (\%) & $8.1 \pm 3.3$ & $1.3 \pm 6.9$ & $0.31 / 0.25^{a}$ & $15.2 \pm 7.8$ & $5.8 \pm 11.0$ & $0.48 / 0.84^{a}$ \\
\hline \multicolumn{7}{|c|}{ Glucagon $(\mathrm{min} \times \mathrm{pmol} / \mathrm{L})$} \\
\hline OGTT & $1238 \pm 123$ & $1283 \pm 154$ & 0.99 & $-404 \pm 82$ & $-515 \pm 88$ & 0.38 \\
\hline$\| G \mid$ & $889 \pm 123$ & $968 \pm 132$ & 0.80 & $-592 \pm 82$ & $-698 \pm 88$ & 0.33 \\
\hline$P$ & $<0.001$ & $<0.001$ & & 0.02 & 0.02 & \\
\hline \multicolumn{7}{|l|}{ GLP-1 (min $\times \mathrm{pmol} / \mathrm{L})$} \\
\hline OGTT & $3125 \pm 199$ & $3247 \pm 222$ & 0.63 & $626 \pm 142$ & $505 \pm 158$ & 0.70 \\
\hline$\| G \mid$ & $1651 \pm 199$ & $1913 \pm 222$ & 0.21 & $-698 \pm 142$ & $-941 \pm 158$ & 0.25 \\
\hline$P$ & $<0.001$ & $<0.001$ & & $<0.001$ & $<0.001$ & \\
\hline \multicolumn{7}{|l|}{$\mathrm{GIP}(\min \times \mathrm{pmol} / \mathrm{L})$} \\
\hline OGTT & $8946 \pm 534$ & $8159 \pm 556$ & 0.23 & $5290 \pm 613$ & $4664 \pm 644$ & 0.33 \\
\hline$\| G \mid$ & $1964 \pm 534$ & $2081 \pm 556$ & 0.86 & $-1523 \pm 613$ & $-1898 \pm 644$ & 0.64 \\
\hline$P$ & $<0.001$ & $<0.001$ & & $<0.001$ & $<0.001$ & \\
\hline
\end{tabular}

Data are means \pm S.E.M. Significant $P$ values $(<0.05)$ are shown in bold.

${ }^{a}$ Adjusted for age, BMI, sex and glucose dose $(75 / 50 \mathrm{~g})$ in a multivariate linear model.

GIP, glucose-dependent insulinotropic polypeptide; GLP-1, glucagon-like peptide 1; IIGI, isoglycemic IV glucose infusion.

$\mathrm{T}$ allele on beta cell function become apparent alongside the development of a defective glucose metabolism.

Our findings are in disagreement with a study in which 56 participants with type 2 diabetes (30 with CT/TT) were studied during a mixed meal test (48). In this study, both heterozygous and homozygous $\mathrm{T}$ allele carriers (CT/TT) were compared to homozygous $\mathrm{C}$ allele carriers (CC). $\mathrm{T}$ allele carriers had higher postprandial levels of proinsulin, insulin and C-peptide, perhaps indicative of a higher degree of insulin resistance in participants with type 2 diabetes and the TCF7L2 rs7903146 risk genotype. This is supported by another study in a cohort of 955 obese youths, in which the TCF7L2 rs7903146 T allele associated with decreased beta cell responsiveness to OGTT and increased hepatic insulin resistance (27). In our rather small data set there was no interaction between the TCF7L2 rs7903146 T allele and insulin sensitivity in any of the groups, in agreement with some but not all earlier studies of the impact of TCF7L2 on insulin sensitivity (12, $19,20,27,32,48,49$ ). A strength of the present study is the use of the gold standard measure of the incretin effect
(OGTT and IIGI) reflecting the impact of endogenous incretins on glucose metabolism and, thus, providing insights into possible pathophysiological mechanisms. In contrast, investigations of supraphysiologic levels of exogenous incretins, as in the abovementioned studies by Schäfer et al. (18) and Pilgaard et al. (19), may reveal defects in the actions of the incretins in supraphysiological levels with particular relevance to incretin-based treatments. Another strength of our study is the sample size of 104 individuals characterized by the OGTT and IIGI method, which is the largest cohort used to evaluate the impact of TCF7L2 genotype on the action of endogenous incretins to date. Our diverging results compared to previous functional studies on the TCF7L2 rs7903146 risk variant may relate to differences in the studied populations including the ratio of heterozygous to homozygous carriers. Limitations worth considering when interpreting our results include potential interstudy variability in assays and other procedures in the 8 investigations on which the present study was based; although these were conducted by the same group using standardized methods.

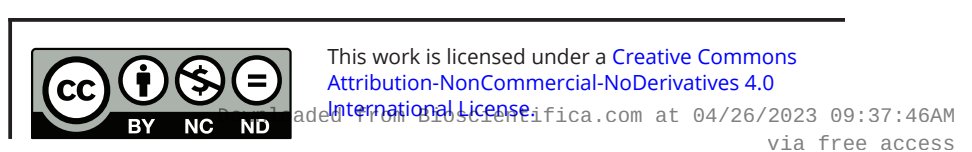


Studying normal glucose tolerant individuals may introduce a bias toward a normal incretin effect in $\mathrm{T}$ allele carriers, whereas any defects in $\mathrm{T}$ allele carriers in the type 2 diabetes group may be obscured by other pathophysiological traits contributing to the diabetic state. Also, the CC and CT/TT groups were not matched 1:1 for age, sex and BMI. Lastly, the total number of subjects included in our analysis was relatively small compared to genetic studies in general and only six homozygous carrier (TT) of TCF7L2 rs7903146 were examined. Nevertheless, we believe that our results contribute importantly to the understanding of the potential influence of rs7903146 on the incretin effect. The lack of influence of rs7903146 on the incretin effect in subjects with normal glucose tolerance and in participants with type 2 diabetes in the present study, does not exclude the possibility of reduced insulinotropic effect of incretins (especially not of exogenous incretins in supraphysiological concentrations) in rs7903146 carriers progressing from a glucose tolerant stage to a prediabetic stage, as seen in studies including individuals with impaired glucose tolerance $(17,18,24)$ or defects not detectable in this study.

In conclusion, we report no detectable changes in incretin effect in these relatively small cohorts of carriers of rs7903146 with normal glucose tolerance and type 2 diabetes, respectively. Additionally, rs7903146 carriers with normal glucose tolerance displayed no defects in glucose metabolism or insulin sensitivity indices. In contrast, rs7903146 carriers with type 2 diabetes were characterized by a diminished C-peptide response and elevated glucose during OGTT; possibly revealing diminished glucose-stimulated insulin secretion in $\mathrm{T}$ allele carriers with type 2 diabetes compared to their $\mathrm{C}$ allele carrier counterparts. Altogether, our findings do not exclude that the mechanistic basis for the increased risk of developing type 2 diabetes in individuals with this specific TCF7L2 variant involves defects in the incretin effect, but using the gold standard method to evaluate the incretin effect, we could not detect any genotype-related defects in these cohorts.

\section{Declaration of interest}

$\mathrm{T} \mathrm{V}$ has served on scientific advisory panels and/or speaker's bureaus for, served as a consultant to and/or received research support from Amgen, AstraZeneca, Boehringer Ingelheim, Bristol-Myers Squibb, Eli Lilly, Gilead, Merck Sharp \& Dohme, Mundipharma, Novo Nordisk, Sanofi and Sun Pharma. F K K has served on scientific advisory panels and/or been part of speaker's bureaus for, served as a consultant to and/or received research support from Amgen, AstraZeneca, Bayer, Boehringer Ingelheim, Carmot Therapeutics, Eli Lilly, Gubra, Lupin, Medlmmune, MSD/Merck, Mundipharma, Norgine, Novo Nordisk, Sanofi and Zealand Pharma. All other authors declare that there is no duality of interest associated with their contribution to this manuscript. All authors declare that the research was conducted in the absence of financial interest and have no conflict of interest.

\section{Funding}

The study was supported by a grant from the Novo Nordisk Foundation (NNF170C0029370).

\section{Prior publication}

Part of the data has been presented as a poster at the 79th Scientific Sessions of the American Diabetes Association, San Francisco, US, June 2019. An abstract has been published from this meeting.

\section{Author contribution statement}

D S M was involved in planning of the study, statistical analysis and writing of the manuscript. J I B was involved in planning of the study, statistical analysis and writing of the manuscript. $\mathrm{KB} \mathrm{H}, \mathrm{A}$ J, $\mathrm{S} \mathrm{H}, \mathrm{A} P$ and $\mathrm{T}$ I were involved in conduction of the clinical experiments. J J $\mathrm{H}$ was involved in analysis of blood samples. A E J and T H were involved in genotyping and analysis of data. T V was involved in planning of the study. A L initiated the study and was involved in planning of the study, collection of samples and writing the manuscript. F K K conceived and initiated the study and was involved in planning of the study, collection of samples and writing the manuscript. All authors critically reviewed the manuscript and approved of the version to be published.

\section{Acknowledgements}

The authors would like to thank all study participants for their invaluable contribution. Also, the authors would like to thank all involved laboratory technicians for their help with data collection and laboratory assistance.

\section{References}

1 Newman B, Selby JV, King MC, Slemenda C, Fabsitz R \& Friedman GD. Concordance for type 2 (non-insulin-dependent) diabetes mellitus in male twins. Diabetologia 198730 763-768. (https://doi.org/10.1007/BF00275741)

2 Pierce M, Keen H \& Bradley C. Risk of diabetes in offspring of parents with non-insulin-dependent diabetes. Diabetic Medicine 199512 6-13. (https://doi.org/10.1111/j.1464-5491.1995.tb02054.x)

3 Unger RH \& Orci L. Glucagon and the a cell: physiology and pathophysiology (first two parts). New England Journal of Medicine 1981304 1518-1524. (https://doi.org/10.1056/ NEJM198106183042504)

4 Bagger JI, Knop FK, Lund A, Vestergaard H, Holst JJ \& Vilsbøll T. Impaired regulation of the incretin effect in patients with type 2 diabetes. Journal of Clinical Endocrinology and Metabolism 201196 737-745. (https://doi.org/10.1210/jc.2010-2435)

5 Nauck M, Stöckmann F, Ebert R \& Creutzfeldt W. Reduced incretin effect in type 2 (non-insulin-dependent) diabetes. Diabetologia 1986 29 46-52. (https://doi.org/10.1007/BF02427280)

6 Holst JJ. On the physiology of GIP and GLP-1. Hormone and Metabolic Research 200436 747-754. (https://doi.org/10.1055/s-2004-826158)

7 Vilsbøll T, Krarup T, Madsbad S \& Holst JJ. Both GLP-1 and GIP are insulinotropic at basal and postprandial glucose levels and contribute nearly equally to the incretin effect of a meal in healthy subjects. Regulatory Peptides 2003114 115-121. (https://doi.org/10.1016/ s0167-0115(03)00111-3) https://ec.bioscientifica.com https://doi.org/10.1530/EC-20-0471 (c) 2020 The authors Published by Bioscientifica Ltd
This work is licensed under a Creative Commons Attribution-NonCommercial-NoDerivatives 4.0 International License . $_{\text {fica }}$ com at $04 / 26 / 202309: 37: 46 \mathrm{Am}$ 
8 Grant SFA, Thorleifsson G, Reynisdottir I, Benediktsson R, Manolescu A, Sainz J, Helgason A, Stefansson H, Emilsson V, Helgadottir A, et al. Variant of transcription factor 7-like 2 (TCF7L2) gene confers risk of type 2 diabetes. Nature Genetics 200638 320-323. (https://doi.org/10.1038/ng1732)

9 Damcott CM, Pollin TI, Reinhart LJ, Ott SH, Shen H, Silver KD, Mitchell BD \& Shuldiner AR. Polymorphisms in the transcription factor 7-like 2 (TCF7L2) gene are associated with type 2 diabetes in the Amish: replication and evidence for a role in both insulin secretion and insulin resistance. Diabetes 200655 2654-2659. (https://doi.org/10.2337/db06-0338)

10 Saxena R, Gianniny L, Burtt NP, Lyssenko V, Giuducci C, Sjögren M, Florez JC, Almgren P, Isomaa B, Orho-Melander M, et al. Common single nucleotide polymorphisms in TCF7L2 are reproducibly associated with type 2 diabetes and reduce the insulin response to glucose in nondiabetic individuals. Diabetes 200655 2890-2895. (https://doi.org/10.2337/db06-0381)

11 Cauchi S, El Achhab Y, Choquet H, Dina C, Krempler F, Weitgasser R, Nejjari C, Patsch W, Chikri M, Meyre D, et al. TCF7L2 is reproducibly associated with type 2 diabetes in various ethnic groups: a global meta-analysis. Journal of Molecular Medicine 200785 777-782. (https://doi.org/10.1007/s00109-007-0203-4)

12 Lyssenko V, Lupi R, Marchetti P, Del Guerra S, Orho-Melander M, Almgren P, Sjögren M, Ling C, Eriksson KF, Lethagen AL, et al. Mechanisms by which common variants in the TCF7L2 gene increase risk of type 2 diabetes. Journal of Clinical Investigation 2007 117 2155-2163. (https://doi.org/10.1172/JCI30706)

13 Zeggini E, Scott LJ, Saxena R, Voight BF, Marchini JL, Hu T, de Bakker PIW, Abecasis GR, Almgren P, Andersen G, et al. Meta-analysis of genome-wide association data and large-scale replication identifies additional susceptibility loci for type 2 diabetes. Nature Genetics 2008 40 638-645. (https://doi.org/10.1038/ng.120)

14 Shao W, Wang D, Chiang YT, Ip W, Zhu L, Xu F, Columbus J, Belsham DD, Irwin DM, Zhang H, et al. The Wnt signaling pathway effector TCF7L2 controls gut and brain proglucagon gene expression and glucose homeostasis. Diabetes 201362 789-800. (https://doi. org/10.2337/db12-0365)

15 Xia Q, Chesi A, Manduchi E, Johnston BT, Lu S, Leonard ME, Parlin UW, Rappaport EF, Huang P, Wells AD, et al. The type 2 diabetes presumed causal variant within TCF7L2 resides in an element that controls the expression of ACSL5. Diabetologia 201659 2360-2368. (https://doi.org/10.1007/s00125-016-4077-2)

16 Gjesing AP, Kjems LL, Vestmar MA, Grarup N, Linneberg A, Deacon CF, Holst JJ, Pedersen O \& Hansen T. Carriers of the TCF7L2 rs7903146 TT genotype have elevated levels of plasma glucose, serum proinsulin and plasma gastric inhibitory polypeptide (GIP) during a meal test. Diabetologia 201154 103-110. (https://doi.org/10.1007/ s00125-010-1940-4)

17 Villareal DT, Robertson H, Bell GI, Patterson BW, Tran H, Wice B \& Polonsky KS. TCF7L2 variant rs7903146 affects the risk of type 2 diabetes by modulating incretin action. Diabetes 201059 479-485. (https://doi.org/10.2337/db09-1169)

18 Schäfer SA, Tschritter O, Machicao F, Thamer C, Stefan N, Gallwitz B, Holst JJ, Dekker JM, t'Hart LM, Nijpels G, et al. Impaired glucagonlike peptide-1-induced insulin secretion in carriers of transcription factor 7-like 2 (TCF7L2) gene polymorphisms. Diabetologia 200750 2443-2450. (https://doi.org/10.1007/s00125-007-0753-6)

19 Pilgaard K, Jensen CB, Schou JH, Lyssenko V, Wegner L, Brøns C, Vilsbøll T, Hansen T, Madsbad S, Holst JJ, et al. The T allele of rs7903146 TCF7L2 is associated with impaired insulinotropic action of incretin hormones, reduced $24 \mathrm{~h}$ profiles of plasma insulin and glucagon, and increased hepatic glucose production in young healthy men. Diabetologia 200952 1298-1307. (https://doi. org/10.1007/s00125-009-1307-x)

20 Færch K, Pilgaard K, Knop FK, Hansen T, Pedersen O, Jørgensen T $\&$ Holst JJ. Incretin and pancreatic hormone secretion in Caucasian non-diabetic carriers of the TCF7L2 rs7903146 risk T allele. Diabetes, Obesity and Metabolism 201315 91-95. (https://doi.org/10.1111/ j.1463-1326.2012.01675.x)

21 Smushkin G, Sathananthan M, Sathananthan A, Dalla Man C, Micheletto F, Zinsmeister AR, Cobelli C \& Vella A. Diabetesassociated common genetic variation and its association with GLP-1 concentrations and response to exogenous GLP-1. Diabetes $20126 \mathbf{6 1}$ 1082-1089. (https://doi.org/10.2337/db11-1732)

22 Srinivasan S, Kaur V, Chamarthi B, Littleton KR, Chen L, Manning AK, Merino J, Thomas MK, Hudson M, Goldfine A, et al. TCF7L2 genetic variation augments incretin resistance and influences response to a sulfonylurea and metformin: the study to understand the genetics of the acute response to metformin and glipizide in humans (SUGAR-MGH). Diabetes Care 201841 554-561. (https://doi.org/10.2337/dc17-1386)

23 Heni M, Ketterer C, Thamer C, Herzberg-Schäfer SA, Guthoff M, Stefan N, Machicao F, Staiger H, Fritsche A \& Häring HU. Glycemia determines the effect of type 2 diabetes risk genes on insulin secretion. Diabetes 201059 3247-3252. (https://doi.org/10.2337/ db10-0674)

24 Galderisi A, Tricò D, Pierpont B, Shabanova V, Samuels S, Man CD, Galuppo B, Santoro N \& Caprio S. A Reduced incretin effect mediated by the rs7903146 variant in the TCF7L2 gene is an early marker of $\beta$-cell dysfunction in obese youth. Diabetes Care 202043 2553-2563. (https://doi.org/10.2337/dc20-0445)

25 Vazquez-Roque MI, Camilleri M, Vella A, Carlson P, Laugen J \& Zinsmeister AR. Association of TCF7L2 allelic variations with gastric function, satiation, and GLP-1 levels. Clinical and Translational Science 20114 183-187. (https://doi.org/10.1111/j.1752-8062.2011.00284.x)

26 Silbernagel G, Renner W, Grammer TB, Hügl SR, Bertram J, Kleber ME, Hoffmann MM, Winkelmann BR, März W \& Boehm BO. Association of TCF7L2 SNPs with age at onset of type 2 diabetes and proinsulin/insulin ratio but not with glucagon-like peptide 1 . Diabetes/Metabolism Research and Reviews 201127 499-505. (https:// doi.org/10.1002/dmrr.1194)

27 Cropano C, Santoro N, Groop L, Dalla Man C, Cobelli C, Galderisi A, Kursawe R, Pierpont B, Goffredo M \& Caprio S. The rs7903146 variant in the TCF7L2 gene increases the risk of prediabetes/ type 2 diabetes in obese adolescents by impairing $\beta$-cell function and hepatic insulin sensitivity. Diabetes Care 201740 1082-1089. (https://doi.org/10.2337/dc17-0290)

28 Engelbrechtsen L, Hansen TH, Mahendran Y, Pyl P, Andersson E, Jonsson A, Gjesing A, Linneberg A, Jørgensen T, Hansen T, et al. Homozygous carriers of the TCF7L2 rs7903146 T-allele show altered postprandial response in triglycerides and triglyceride-rich lipoproteins. Scientific Reports 20177 43128. (https://doi.org/10.1038/ srep43128)

29 Le Bacquer O, Kerr-conte J, Gargani S, Delalleau N, Huyvaert M, Gmyr V, Froguel P, Neve B \& Pattou F. TCF7L2 rs7903146 impairs islet function and morphology in non-diabetic individuals. Diabetologia 201255 2677-2681. (https://doi.org/10.1007/s00125-012-2660-8)

30 Loos RJF, Franks PW, Francis RW, Barroso I, Gribble FM, Savage DB, Ong KK, O'Rahilly S \& Wareham NJ. TCF7L2 Polymorphisms Modulate Proinsulin Levels and $\beta$-Cell Function in a British Europid Population. Diabetes 200756 1943-1947. (https://doi.org/10.2337/ db07-0055)

31 Daniele G, Gaggini M, Comassi M, Bianchi C, Basta G, Dardano A Miccoli R, Mari A, Gastaldelli A \& Prato SD. Glucose metabolism in high risk subjects for Type 2 diabetes carrying the rs7903146 TCF7L2 gene variant. Journal of Clinical Endocrinology and Metabolism 2015 100 E1160-E1167. (https://doi.org/10.1210/jc.2015-1172)

32 Wegner L, Hussain MS, Pilgaard K, Hansen T, Pedersen O, Vaag A \& Poulsen P. Impact of TCF7L2 rs7903146 on insulin secretion and action in young and elderly Danish twins. Journal of Clinical Endocrinology and Metabolism 200893 4013-4019. (https://doi. org/10.1210/jc.2008-0855) 
33 Florez JC, Jablonski KA, Bayley N, Pollin TI, de Bakker PIW, Shuldiner AR, Knowler WC, Nathan DM \& Altshuler D. TCF7L2 polymorphisms and progression to diabetes in the diabetes prevention program. New England Journal of Medicine 2006355 241-250. (https://doi.org/10.1056/NEJMoa062418)

34 Knop FK, Aaboe K, Vilsbøll T, Vølund A, Holst JJ, Krarup T $\&$ Madsbad S. Impaired incretin effect and fasting hyperglucagonaemia characterizing type 2 diabetic subjects are early signs of dysmetabolism in obesity. Diabetes, Obesity and Metabolism 201214 500-510. (https://doi.org/10.1111/j.14631326.2011.01549.x)

35 Muscelli E, Mari A, Casolaro A, Camastra S, Seghieri G, Gastaldelli A Holst JJ \& Ferrannini E. Separate impact of obesity and glucose tolerance on the incretin effect in normal subjects and Type 2 diabetic patients. Diabetes 200857 1340-1348. (https://doi. org/10.2337/db07-1315)

36 Junker AE, Gluud L, Holst JJ, Knop FK \& Vilsbøll T. Diabetic and nondiabetic patients with nonalcoholic fatty liver disease have an impaired incretin effect and fasting hyperglucagonaemia. Journal of Internal Medicine 2016279 485-493. (https://doi.org/10.1111/ joim.12462)

37 Hansen KB, Vilsbøll T, Bagger JI, Holst JJ \& Knop FK. Reduced glucose tolerance and insulin resistance induced by steroid treatment, relative physical inactivity, and high-calorie diet impairs the incretin effect in healthy subjects. Journal of Clinical Endocrinology and Metabolism 201095 3309-3317. (https://doi.org/10.1210/jc.20100119)

38 Idorn T, Knop FK, Jørgensen M, Holst JJ, Hornum M \& FeldtRasmussen B. Gastrointestinal factors contribute to glucometabolic disturbances in nondiabetic patients with end-stage renal disease. Kidney International 201383 915-923. (https://doi.org/10.1038/ ki.2012.460)

39 Lund A, Vilsbøll T, Bagger JI, Holst JJ \& Knop FK. The separate and combined impact of the intestinal hormones, GIP, GLP-1, and GLP-2, on glucagon secretion in type 2 diabetes. American Journal of Physiology: Endocrinology and Metabolism 2011300 E1038-E1046. (https://doi.org/10.1152/ajpendo.00665.2010)

40 Østoft SH, Bagger JI, Hansen T, Pedersen O, Holst JJ, Knop FK $\&$ Vilsbøll T. Incretin effect and glucagon responses to oral and intravenous glucose in patients with maturity-onset diabetes of the young - type 2 and type 3. Diabetes 201463 2838-2844. (https://doi. org/10.2337/db13-1878)
41 Plamboeck A, Veedfald S, Deacon CF, Hartmann B, Wettergren A, Svendsen LB, Meisner S, Hovendal C, Knop FK, Vilsbøll T, et al. Characterisation of oral and i.v. glucose handling in truncally vagotomised subjects with pyloroplasty. European Journal of Endocrinology 2013169 187-201. (https://doi.org/10.1530/EJE-13-0264)

42 Turner S, Armstrong LL, Bradford Y, Carlson CS, Crawford DC, Crenshaw AT, Andrade M de, Doheny KF, Haines JL, Hayes G, et al. Quality control procedures for genome-wide association studies. Current Protocols in Human Genetics 201168 1.19.1-1.19.18. (https:// doi.org/10.1002/0471142905.hg0119s68)

43 Phillips DI, Clark PM, Hales CN \& Osmond C. Understanding oral glucose tolerance: comparison of glucose or insulin measurements during the oral glucose tolerance test with specific measurements of insulin resistance and insulin secretion. Diabetic Medicine 199411 286-292. (https://doi.org/10.1111/j.1464-5491.1994.tb00273.x)

44 Mari A, Pacini G, Murphy E, Ludvik B \& Nolan JJ. A model-based method for assessing insulin sensitivity from the oral glucose tolerance test. Diabetes Care 200124 539-548. (https://doi. org/10.2337/diacare.24.3.539)

45 Knop FK. Comment on: Villareal et al. (2009) TCF7L2 variant rs7903146 affects the risk of type 2 diabetes by modulating incretin action. Diabetes;59:479-485. Diabetes 201059 e4. (https://doi. org/10.2337/db10-0236)

46 Calanna S, Christensen M, Holst JJ, Laferrère B, Gluud LL, Vilsbøll T $\&$ Knop FK. Secretion of glucose-dependent insulinotropic polypeptide in patients with type 2 diabetes: systematic review and meta-analysis of clinical studies. Diabetes Care 201336 3346-3352. (https://doi.org/10.2337/dc13-0465)

47 Saxena R, Hivert MF, Langenberg C, Tanaka T, Pankow JS, Vollenweider P, Lyssenko V, Bouatia-Naji N, Dupuis J, Jackson AU, et al. Genetic variation in GIPR influences the glucose and insulin responses to an oral glucose challenge. Nature Genetics 201042 142-148. (https://doi.org/10.1038/ng.521)

48 Ferreira MC, da Silva MER, Fukui RT, Arruda-Marques MDC \& dos Santos RF. TCF7L2 correlation in both insulin secretion and postprandial insulin sensitivity. Diabetology and Metabolic Syndrome 201810 37. (https://doi.org/10.1186/s13098-018-0338-1)

49 Rasmussen-Torvik LJ, Pankow JS, Jacobs DR \& Sinaiko AR. No association between TCF7L2 rs7903146 and euglycemic-clamp derived insulin sensitivity in a mixed-age cohort. Metabolism: Clinical and Experimental 200958 1369-1371. (https://doi.org/10.1016/j. metabol.2009.04.023)

Received in final form 29 October 2020 Accepted 2 November 2020

Accepted Manuscript published online 3 November 2020 https://ec.bioscientifica.com https://doi.org/10.1530/EC-20-0471 (c) 2020 The authors Published by Bioscientifica Ltd
This work is licensed under a Creative Commons Attribution-NonCommercial-NoDerivatives 4.0 enternationab ficense.ifica . com at 04/26/2023 09:37:46AM 